\title{
Defamiliarizing War: A Formalist Reading of the Graphic Novel The Pride of Baghdad
}

\author{
Dr. Engy Salah Tawfeek Saleh
}

Lecturer-Damietta Faculty of Arts

\section{Abstract:}

The research aims at introducing a formalist reading of the American graphic novel The Pride of Baghdad (2006) knocking heavily on defamiliarization as a guiding term of reference. The research deals with how war is defamiliarized through the use of the graphic narrative form, on one hand, and the use of animal allegory, on the other. Implied in the very core of the graphic novel is the idea of form that delves deep through an impressionistic technique clearly assisted by ellipsis, to foreground freedom as a major theme from which sprouts the theme of 'otherness'. In the novel, the American invasion of Iraq is reformulated and re-presented from the vantage point of a pride of lions. Ellipsis is given a due analysis as an important artistic technical component of the novel. It is employed in such a way that arouses the role of the pictures in completing the meaning and complementing the mental images in the minds of the readers. The Pride of Baghdad proves to fit perfectly into a formalist literary context of analysis through tracing how it defamiliarizes war through graphically encoding its effect in its influence on a pride of lions.

Key Words:

Graphic novel- The Pride of Baghdad- defamiliarization- animal allegory- ellipsis- impressionism

العدد الرابع والعشرون (الجزء الثالث) 2018

()

بجلة كلية التربية- جامعة عين شمس87 


\section{تغريب الحرب: قراءة شكلية للرواية المصورة كبرياء بغداد}

\section{ملخص}

يهدف البحث الى تقديم قراءة شكلية للرواية المصورة كبرياء بغداد (2006) للكاتب

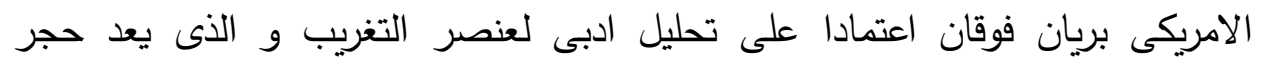

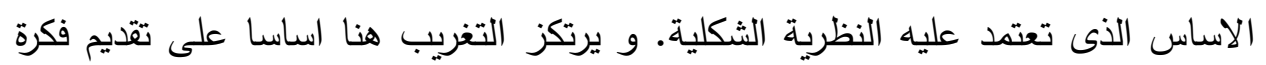

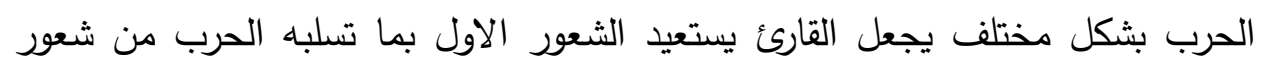

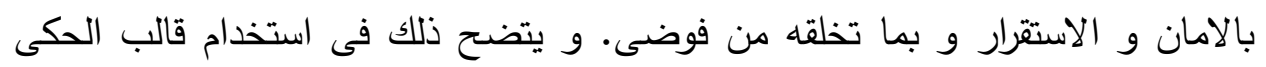

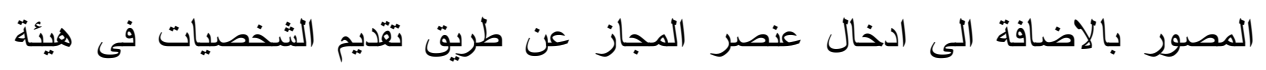

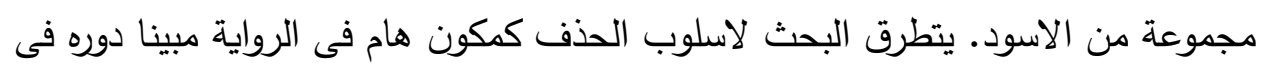
تدعيم القالب المصور فى الحكى حيث يتم حذف بعض الكلمات ليجول القارئ بعينيه ليستكملها من الصور فيكتمل المعنى و تصل الرسالة. و يشير البحث ايضا الى نظرية

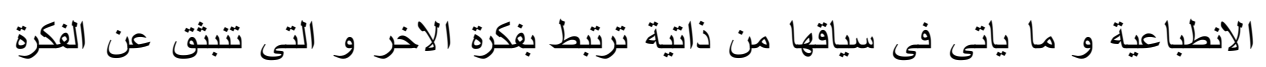

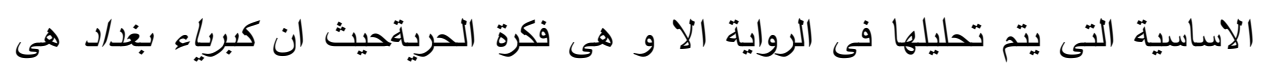

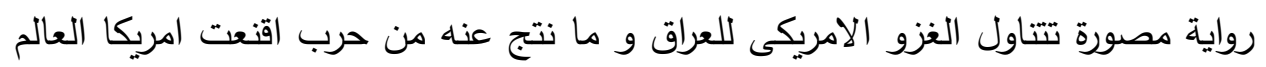
انها شنتها لتحرير العراق و العراقين من سيطرة الرئيس العراقى صدام حسين. شكل مله الرواية الفنى هو الاساس الذى يعبر عنه الكاتب عن رؤيته و بالتالى تكون هذه الرواية سياق مثالى لتطبيق النظرية الشكلية و خاصة مفهوم التغريب. كلمات مفتاحية: الرواية المصورة- كبرياء بغداد- التغريب- الحرية- المجاز بالحيوان 


\section{Defamiliarizing War: A Formalist Reading of the Graphic Novel The Pride of Baghdad}

"In face of such enormous facts of destruction.... One finds it in the midst of all this as hard to apply one's words as to endure one's

\section{thought" \\ Henry James \\ Dr. Engy Salah Tawfeek Saleh \\ Lecturer-Damietta Faculty of Arts}

Though war is a universal topic that has pervaded literary works all over the world, its literary representation has lost its immediate influence on readers who have become used to this negative psychological effect atrocities and crimes are supposed to bring about in their minds and hearts. With all its destructiveness, war has deprived words of their effect. Here comes the role that literature plays in restoring the reader's perception of such experiences by breaking up the familiarity of the experience itself for the sake of reliving it anew. Investigated within this framework, the graphic novel The Pride of Baghdad (2006) proves to be one of these war novels in which war is literary manipulated and represented, but in a different way that would restore the same effect words have lost. The novel deals with the impact of the American invasion of Iraq (2003) and the resulting war from the perspective of a pride of lions escaping from the zoo of Baghdad. The novel is not concerned with the many extreme atrocities of the American war in Iraq as much as it is related to the theme of freedom as a constituent factor of influence. In analyzing this graphic novel, the research works on proving that the graphic form is in itself a defamiliarizing tool used concomitantly with animal allegory to speak about freedom. It traces the way war is defamiliarized through combining the visual and the verbal to captivate the readers, getting them deeper beyond the surface

العدد الرابع والعشرون (الجزء الثالث) 2018

()

بجلة كلية التربية- جامعل عين شمس 
structure of the novel towards perceiving how traumatic war is and how valuable freedom is. This is done in an attempt to show that the visual enhances the verbal, uplifts the readers' mental image and consolidates the concept. Here, the readers are mesmerized and enchanted enough to feel the pain; they are moved through the pictures, i.e. visual, to experience what the words tell, i.e. verbal. Images are given so that the speechless creatures are introduced to speak out through them holding both the narratological and the thematic threads of the novel tight together. Thus, the defamiliarizing process here is twofold, as it comprises a graphic representation, on one hand, and an animal employment, on the other working together to bring forth what Barthes calls "referential illusion". Extending the formalist reading of the novel, ellipsis is introduced as a technical feature that complements and supports the use of images and pictures bringing forth impressionism as a potential analytical approach.

It is important to note here that graphic novels, in general, have been commonly attached to children literature and comics. In other words, the term itself was created as an alternative to comic books "in an effort to overcome the stigmas of humor and childishness of the word "comics" (P. Gravett 8). Here, this formula is turned wider to encompass all literary representation of human experiences making use of a visual manipulation that is supposed to support and consolidate the verbal. This is intensified by the nature of the experience tackled in the selected novel i.e. war, since war stands in direct opposition to the childish strand that used to characterize comics representing one of the most serious traumatic human experiences ever. War unravels the true nature of people and things as it puts all of them in direct contact with danger; something that challenges in them the instinct for survival. This proves that "comics are a medium capable of exploring themes every bit as serious as those studied by any prose novel" (M. Pedersen 32).

العدد الرابع والعشرون (الجزء الثالث) 2018

()

بجلة كلية التربية- جامعل عين شمس90 
Again the proposition held here goes further when it focuses on portraying such an experience from the vantage point of a pride of lions i.e. animals, as if the unspoken pain and trauma has exceeded the limits of the human border to the arena of the unspeaking 'nonhuman other'. The otherness of the Iraqi people, in relation to the Americans, is artistically investigated against the animal otherness in the novel unlocking a lot of other thematic undercurrents such as inferiority, oppression and silent suffering. This develops through portraying a complex of relationships: between the keepers, i.e. humans, and the lions, i.e. non-humans; among animals themselves; and between the lions and the American soldiers. The unspoken is articulated in the novel through an artistic mix between words and pictures to introduce the readers to a unique mixture of both technical and thematic innovation.

The Pride of Baghdad is a graphic novel that is written by Brian Vaughan and illustrated by Niko Henrichon. It is based on a true story related to rescuing the animals in Baghdad Zoo, that was first established by Saddam Hussein in 1971 as the largest zoo in the Middle East. The animals freed themselves after all the area was heavily bombed, and three of them were shot dead after they attacked US soldiers. The novel is mainly concerned with the male lion Zill, the older lioness Safa, the younger lioness Noor and her male cub Ali. Two males and two females; two old and two young represent the everlasting unresolved conflict between stability and freedom. The cast of characters in The pride of Baghdad varies in age, gender and species fulfilling an important condition in comics. In this regard, Scott Mccloud states that it is a necessity in comics that the "cast of characters should represents a full spectrum of approaches to life" (69). Before the war, all the animals were safe and stable in their cages in the zoo. After the war, they are free, but scared, threatened and finally shot dead while they were searching for something to eat. The question posed here is: 'Is freedom just getting out of borders?' This conflict is intensified in the novel

العدد الرابع والعشرون (الجزء الثالث) 2018

()

بجلة كلية التربية- جامعة عين شمس 
through the images that drag the readers' attention and immerse them into the scene.

Analyzing such a novel, one could easily feel the novelty of the literary representation within the frame of which war is introduced. From this novelty comes the possibility of applying defamiliarization as a key term that could work elaborately on engaging the readers into the novel. Defamiliarization is a common critical term that is attributed to formalism. It rests on a deep awareness of the proposition that "one function of art and literature is to disturb its audience's routine .... The techniques of defamiliarization include placing characters and events in unfamiliar contexts" (Quinn 112). Through form, the reader is reoriented to reconsider what s/he had kept secure and safe within the stable framework of habit and repetitive casualties. As a result, the comic strips that changed to graphic representation have been a new form into which is poured a defamiliarizing attempt at creating a new perception of old ragged experiences and feelings. Such a feeling or experience is reformulated in an artistically manipulated manner and is brought into the minds of the readers anew. Shyklovsky, the formalist leading figure puts in the proposition that it is very important "to make forms difficult, to increase the difficulty and length of perception because the process of perception is an aesthetic end in itself and must be prolonged." (20). In other words, it is brought in a new fabric that obliges the readers to investigate thoroughly before it unravels into the well-known texture they discover themselves familiar with. At that moment, each and every detail is rediscovered and perceived differently leading the readers to an epiphanic moment in which the old ragged sensation is renovated and a new realization of an old experience is artistically summoned.

العدد الرابع والعشرون (الجزء الثالث) 2018 
The importance of defamiliarizing war lies mainly in its artistic effect on the readers. It comes from a deep rooted tradition of habituation that has rendered the real and the semi-real unbelievable, yet keeps the imaginary more influential and effective. Readers who turn off their T.Vs in order not to watch news about the dead and the injured in Iraq, Afghanistan, Palestine, etc., open up their minds and hearts to their novels and DVDs to watch science fiction and fantastic movies addressing the same destructive impacts of war, but in different contextual representation. They may weep for the death of an actor in the movie though they never saw the real person whom he stands for. This brings in Barthes' term "referential illusion", explained as follows:

eliminated from the realist speech-act as a signified of denotation, the 'real' returns to it as a signified of connotation; for just when these details are reputed to denote the real directly, all that they do... is signify it... in other words, the very absence of the signified, to the advantage of the referent alone, becomes the very signifier of realism; the reality effect is produced, the basis of that unavowed verisimilitude which forms the aesthetic of all the standard works of modernity." (148).

Referential representation rests on the proposition that in artistic representation, stating directly and blatantly what is real concerning war, just to show it physically, reduces the effect this representation leaves on the readers. It is only when the signified disappears, as a direct denotation, that realism is approached. This disappearance is in itself a sign of realism. With the absence of a direct signified, the mental image is widely broadened, driving the readers to relive the experience, which is then brought closer and more colorful creating a kind of illusion that is much closer to reality. Such an illusionary state plunges the readers in the reality of war and awakens in them the pain and depression it usually brings.

العدد الرابع والعشرون (الجزء الثالث) 2018

()

بجلة كلية التربية- جامعة عين شمس93 
A graphic novel is a "Longer-format comic book. Sometimes this is an original work or

often it can be a compilation of smaller volumes published earlier." (Petersen 252). The term 'graphic novel' was first mentioned by David Kunzle in the second volume of his book The History of the Comic Strip, but no definition was given to the term in this book. 'Graphic novels' is another term for comics, though they differ in the form since graphic novels are in book form while comics usually come in periodicals form. Generally speaking, a graphic novel is not a genre in itself as much as "a medium in which many genres are represented." (Weiner 11). As a result, there could appear a science fiction graphic novel, love graphic novel, war graphic novel, etc. Considering classification, and as mentioned by Petersen mentions in his book Comics, Manga and Graphic Novels, critics approached comics, in general, from three main vantage points. The first point is mainly concerned with formalism since critics, like Mccloud, Spiegelman, Groensteen, , Lefe'vre, Chute, addressed the relationship between words and images as the main entry of analysis. The second point is related to tracing the history of comics and its genealogy, and this was the concern of critics like Kunzle, Witek, Wright and Hatfield. As for the third point, it comes normally to link comics to all the other thematic literary approaches like psychoanalysis, intertextuality, post-colonialism, etc. Another classification is discussed in Robert G. Weiner's book Graphic novels and comics in libraries and archives, and it rests on a chronological order that classifies graphic novels according to time periods they appeared in. There are the graphic novels of the Golden Age (1938-1944); the Atomic Age (1944-1956); Silver Age (1956-1972); Bronze Age (1972-1986); Modern Age (1986present).

العدد الرابع والعشرون (الجزء الثالث) 2018

()

بجلة كلية التربية- جامعة عين شمس94 


\section{Dr. Engy Salah Tawfeek Saleh}

Asserting the importance of 'form' in graphic novels, one should point to the fact that graphic narratives present a new form of narratology that keeps them always grasping i.e. non-narratorial representation. Non-narratorial representation brings into discussion the medium used in bridging the gap between the writer and the reader. This bridging does not depend, as in ordinary novels, on verbal narration on the part of the narrator. It exceeds to bringing in pictures that shift the medium to a "verbal-pictorial mode of representation." (J. Thon 82). These pictures widens out the mental images in our minds trespassing all what could be logical. As Thomas Kretchmar states in The Power of Inner Pictures, "[e]ffective imaginings often detach themselves from logical reasoning. They are much less a matter of the mind than of the emotions. Their powers tend to unfold best when they are joined by intense emotional experiences." (13). The power of whatever is presented is magnified by the workings of imagination that is based on going far from what is logically accepted or anticipated. Constructing images or pictures widens up one's imagination and consolidates the emotional effect intended. The powerful effects of pictures and images finds an evidence in the success made by Thomas Hirschhorn's artistic work The Incommensurable Banner (2007), that is composed of an eighteen-meter banner on which are collaged lots of photos of killed and mutilated Iraqi cilvilians; photos that were banned from the West media representation of the Iraqi war.

By getting animals to dominate the scene as the main characters of the novel, war is artistically defamiliarized dragging the main thematic texture of the novel towards freedom as a primary concern. Here, a group of lions are used to delineate an animal allegory that holds a double-facet function. First, it presents the human current status from the view point of a group of lions that are given human attributes creating a new perception of war and freedom. They talk, feel, fight, and betray, etc. representing the status of the Iraqi people

العدد الرابع والعشرون (الجزء الثالث) 2018

()

بجلة كلية التربية- جامعة عين شمس95 
who were divided into two main groups: one group who regarded the strict rules of President Saddam Hussein as despotism and dictatorship, and tried to resist him. The second group consists of those people who preferred the stability of dictatorship to the instability of liberty. Throughout the dialogues among the four lions, one could easily feel the tension between two contradictory ideas concerning freedom. The use of animals "introduces a mix of humor and seriousness, of tragedy and the comic. They entertain and instruct while at the same time unsettling us." (B. Shaw 5). On another side, the lions are introduced as mere animals, not as humans. They symbolize a second eye that judges human behavior from an outside perspective, which is non-human, of course. This is very clearly represented in the turtle scene, when the turtle speaks about humans as nothing but "walkers" (61). The turtle, together with the lions and the other animals, is on one side against that of the humans. The two functions are both gathered in one single scene in which Zill is introduced both as a "hunter", an animal, and a "fighter", an almost human attribute (99). In an animal category, "With an equivalent or greater than human intelligence [the animal] confronts questionable human values, such as war, killing and cruelty .... Finally, by choice or mischance it returns to its former intelligence and/or dies" (Shaw 72). This applies to The Pride of Baghdad, with the lions killed by the American soldiers, at the very end of the novel.

In both cases, the animal allegory serves perfectly as a defamiliarizing tool in the novel, addressing what Maccloud calls "bilateral symmetry" on the part of the readers; here, the reader says, "Yes, this is an animal like me. This a living thing." (Maccloud 59). They feel the relationship between themselves and animals as parts of the same world. This is the literary site "where left and right are mirror images" (Maccloud 60). This is the same as in the allegory delineated in Orwell's Animal Farm. Like Animal

العدد الرابع والعشرون (الجزء الثالث) 2018

()

بجلة كلية التربية- جامعة عين شمس96 


\section{Dr. Engy Salah Tawfeek Saleh}

Farm, The Pride of Baghdad "reduces its fictional animal characters to simple metaphors for real human subjects" (S. Meighoo 1). Again, the pun used in the title is very indicative as the writer chooses the word 'Pride' to get into one knot both the technical tool of defamiliarization in the novel and its thematic core since the word 'pride' has two meanings here. It refers, in one meaning, to the group of lions, on which the animal allegory in the novel is based. In the other meaning, 'pride' refers to the dignity and sense of honor Baghdad has been clinging to in fighting the American forces after the invasion, and here lies the reference to the theme of freedom as tackled and traced in the novel.

In graphic novels, pictures serve as a stepping tool towards reaching a meaning through motivating the reader to link the visual sign represented in the pictures to the verbal represented in the printed words. The point here is that the reader of a graphic novel is immersed in reading since "by looking over the whole picture and seeing the relationships between the smaller individual pictures, with some empty and others filled with interlocking forms, the reader apprehends a sense of movement over time."(Petersen xv). The system of signs here is replicated to involve not only the written but also the drawn. The writer and the painter both reflect their own visions formulated in different forms but fabricated into a single semiotic frame of meaning. Though the writing and the drawing are done separately by two different people, the reader receives both simultaneously while reading the novel. Consequently, there must be a sort of harmony between the writing and the drawing so that they complement each other. The reader, thus, is involved in a challenge that necessitates him/her to synthesize both domains. In this regard, Antony Browne writes that "What excites me... is working out the rhythm of the story and seeing how much is told by the pictures, how much by the words, and how much by the gaps between the two" (194). Stimulated by the two visions is created one whole vision that fills in what is missing in both. It is

العدد الرابع والعشرون (الجزء الثالث) 2018

()

بجلة كلية التربية- جامعة عين شمس 
necessarily required that both the writer and the painter have the same idea or artistic vision as much as it is required that they go in tune so that they are able to direct the reader towards a certain destination.

The Pride of Baghdad starts with a croak setting the scene by saying "the sky is falling" (9). However, it would have been impossible to reach the true meaning without the picture of the military planes in the following panel. This panel is unframed and it takes the whole page without any speech balloons. Here, the novel's framework is set clearer to address war as a thematic icon in the novel. In the third page, there is a panel showing the croak flying in an attempt to escape, with the label 'Baghdad Zoo' foregrounded in a straight framed panel. The next panel introduces the readers to the old lion 'Zill' and the old lioness 'Safa'. In such a way, the verbal and the visual are united together in such a way that brings in the signifier and the signified into one semantic crucible, leaving it for the readers to assemble all the parts together.

Not a word is written to signify war, but many clues are drawn to represent it. The military planes in the sky, the label 'Baghdad Zoo', the soldiers, and the ruins, are the readers' clues in setting the scene spatially and temporally. The novel rests partially in using such 'memes', such as the 'Victory Arch' to set a cultural, social, regional and national setting for the reader to properly situate the experience presented. Coined by Richard Dawkins in 1976, a meme has come to denote a carrier of any cultural ideas, symbols, or practices, which go on from one generation another through the visual, audio media of communication. Such pictures of bodies and facial expressions endow the novel with a "kind of spontaneity and allow the reader to see the action represented as if it is happening or unfolding before the reader's eyes." (Petersen xvii).

العدد الرابع والعشرون (الجزء الثالث) 2018

()

بجلة كلية التربية- جامعة عين شمس98 
One cannot leave without pointing to the irony brought into the very depth of the novel when war is drawn to pave the way for freedom. Here, war is synonymous to invasion. The American invasion of Iraq is the animals' only chance for liberation and freedom. Noor, the younger lioness, is holding an attempt at resistance against the humans who keep them imprisoned in the cages of the zoo. She tries to convince the antelope to help her escape from the zoo saying, "We can't wait around for some miracle to change the world for us. We have to take control of our own destinies!" (13). For her, everything has lost its meaning and flavor since she has been stripped off her freedom. When her son, Ali, comes to call her for lunch, she resents having rabbits for lunch because they are directly handed to them without any effort in hunting them; she "miss[es] the thrill of the hunt" (Vaughan 16).

In the same panel, there is a speech balloon saying "Don't listen to her, child ..." (16). Here the notion of conflicting views regarding freedom is contextualized. Noor looks at freedom from a mere physical vantage point. Being imprisoned and restricted beyond the bars of cages for her can never be freedom; freedom has no limits. It "becomes projected backwards either as a historical or a personal memory in a way that allows a sense of future continuity only through a shifting perception of 'home'." (K. Kanneh 67). Noor never regards the zoo her 'home' and, consequently, lacks that sense of belonging on which her freedom depends. For her, only the wild is her real 'home', and it is only there that she could feel free. She constructs in her mind a safe spot from the past that guides her present towards future. Freedom becomes a dream to be attained in the future only through reformulating the past by means of restoring her real 'home', towards the wild and away from the zoo

On the other hand, Safa looks at freedom from a wider perspective. She considers stability a key word for freedom. Addressing Noor, she says, "if you had any real memories of the old days, I doubt you

العدد الرابع والعشرون (الجزء الثالث) 2018

()

بجلة كلية التربية- جامعة عين شمس99 
would be so eager to revisit them" (17). Iraqi people were supposed to be kept with Saddam Hussein under despotism, but they were safe in their country. The American government tried to convince the world that the Americans came to Iraq to liberate the Iraqis from such despotism. While Noor supports the importance of freedom on the sake of stability, Safa, who saw a lot in her younger age, knows that the state of stability and safety has a price to be paid. For her, kept in the zoo "is the price [she has] to pay for that" (Vaughan 32). In one of the scenes of confrontation between her and Noor, Safa shows how inaccurate and inexperienced Noor is. When Noor remembers killing her first rabbit before being kidnapped from the wild, she is stopped by Safa who says that in the wild, where they used to live, there were no rabbits; only hares existed. Noor, the revolutionary spirit, is portrayed mistaken, lacking the enough experience to guide Ali, i.e. the younger generation, who would only "enjoy [his] reign in hell" (Vaughan 31), if he followed Noor.

Meanwhile, the supposed-to-be king, Zill, is only busy starting to eat one of the rabbits. He does not care for the seeds of conflict being sprouted in his den asking "Can't we eat in peace for once?" (17). Actually, this is a master scene in which Zill, representing the powerful authority who destroys his kingdom by keeping silent regarding the emergence of conflicting and revolutionary undercurrents, is keen on nothing but his materialistic gains, represented here in the rabbits thrown in front of him. Freedom is at stake when left in the hands of irresponsible authorities. There must be a super power that is neither biased nor beneficial. Again, when Noor asks Zill to tell Ali about the horizon, that Ali has never seen before, in the old days, Zill says, "At the end of every day, I watched as the horizon devoured the sun in slow, steady bites, spilling its blood across the azure sky" (23). Here, the horizon symbolizes freedom that devours lives and spills blood in order to be attained and enjoyed. Freedom cannot be achieved unless many 
things are sacrificed. Though the source of light, at some time in the day, the sun has to be sacrificed for the sake of people who love to see that wonderful scene of the sky extending to the infinite with the color of the sun's remaining twinkling light beautifying the scene. Likewise, freedom is beautiful, however painful it is. The great sun which feeds the universe with light and heat since sunrise has to die in order to please the same people who are supposed to protect and adore. It dies just to be born again. Saddam Hussein once held Iraq to the top, but is to be sacrificed for the sake of liberating his people. The American government came to fight Saddam and with Saddam, Iraq was killed not because he destroyed it, but because he wanted to sacrifice everything for its sake. A very indicative action happens when Ali mistakenly imagines the first bombing, with the light it brings, to be the horizon that Zill has told him about. He mistakes destruction for beauty. Another example showing the expense of freedom is Safa's lost eye, that eye which she lost while resisting some brute male lions in the past when she was still free with her pride in the wild.

After the first bombing, a part of the zoo is destroyed and the lions find themselves free without any effort done. Noor, the ever resistant and revolutionary, is perplexed and afraid. She tells Zill "freedom can't be given, only earned" (30) in an indirect reference to what the Americans did in Iraq. The Americans kept on asserting to the whole world that their invasion of Iraq had been an attempt to support the Iraqi people against the despotism of Saddam Hussein. The Americans decided to give the Iraqi people their freedom, which is not theirs in the first place. They tried to convince the world that their quest in the first place was to fight terrorism, personified in Saddam Hussein. They masked their political and economic urges for hegemony with the fake seek for the human universal quest for freedom. While Zill coached the pride to get out of the zoo quickly, Safa refuses to go anywhere else. Here, Zill, and Ali try to convince her, each from a different perspective. For 
example, Zill tells her that if she did not join them, she would die alone. Ali, blinded by his mother's vision of freedom, dreams of being a king in the jungle, that he imagines to be lying outside. He, thus, represents those Iraqi people who thought the Americans would bring them any honor or dignity. It is here when Safa replies, "Then enjoy your reign in Hell. This place might not be perfect but it's better than the alternative" (31). The hell does not wait for long as the readers are immediately driven to a very indicative scene in the next page, which is divided into three vertical panels. The first is a close-up panel for a giraffe expecting that what has happened is her ancestors' answer to her prayers to be saved from her imprisonment. She is crying, "The old ones have heard our prayers! They "re coming to ..." (34). The second panel shows a bomb brought directly to cut off her neck while the third shows her without her neck, with Zill calling for Noor and Ali to move. (34).

Trying to escape the bombing, the three lions: Zill, Noor and Ali are suddenly separated. Ali falls in the hands of the apes who decide to make use of Ali, whose presence would support and fortify their existence as "nobody's gonna stop [them] from taking whatever [they] want" (37). They try to convince Ali that his mother is dead and that they are his family now. Here, it is not difficult to look at Saddam Hussein as the little Ali who fell in the hands of the Americans who tried to convince him that the Arab world is dead and that they are his people now. At the moment Ali realizes that these apes are not friends and he tries to escape, they threaten him. Under pressure, Ali surrenders, like Saddam did when he was manipulated to invade Kuwait. When Noor knows that Ali is kidnapped by the apes, she feels afraid and worried because she knows the apes well as she had had a deal with them before against the keepers. While Zill and Noor are unable to save Ali because of the pond separating them from the Apes' island, Safa who is still there in the zoo, is able to save him after attacking the apes. The 
panel shows Safa with the young Ali on her back, on one side of the panel, and Zill with Noor on the other side, waiting for her to cross the pond on a $\log$ of wood. Now, Safa is obliged to join Zill, Noor and Ali because the apes will not leave her safe and will try to avenge themselves. Here is evidence again to support Safa against Noor in the novel. Safa asks Noor to add rescuing Ali "to the long list of things she doesn't know" (45) referring to her inexperience and ignorance, in some cases.

Another shot drags the readers to the ideas of responsibility and honor as prerequisites for freedom. In an artistically drawn scene, the readers are faced with an animal that sacrifices food for the sake of a promise; Safa tells the rest: "let her tell them that lions always keep their words. Let them all know that the antelopes could have been free ages ago if they had just been brave enough to trust me" (46). Here, the readers encounter a carnivorous fighting her instinct of predation for the sake of a sense of honor, that many humans lack. Before the American invasion, Noor promised the Antelope to keep her and her family safe if they helped her in escaping from the zoo. Now, when she finds nothing to eat but the antelope, she lets her go for the sake of this promise. After the bombing stops, and after they are completely outside the zoo, everything seems quiet and safe with the sun shining and flowers blooming. In the background, they are under the Victory Arch (Qaws Al-Nasr) that was built and opened in 1989 under the reign of Saddam Hussein in commemoration of the victory Iraq achieved in the Iraqi- Iranian war. This is a tourist site and a place where Iraqi national celebrations used to be held. This arch is formed of two outstretched hands holding crossed swords. Everything seems fine and safe in the very beginning as if the lions have earned their freedom at last. However, in a confrontation scene between Noor and Safa, the readers are driven to see clearly the violent nature of the two lionesses through the scary pictures showing both rearing their ugly heads at each other. Noor wants Safa to cheer up and celebrate their 
freedom while Safa believes "This is no victory" (50). She faces Noor with the painful reality saying, "you're either too scared or too stupid to see that what you've been pining for all these years is a mirage." (50). Safa tries to convince Noor that the dream of freedom outside the zoo is nothing but an illusion.

Safa takes Ali to drink from the Tigris River regretting the absence of the fresh water they used to drink in the zoo. There, they meet an ancient turtle that witnessed the first big war and who tells them about things they do not know anything about. Meanwhile, the ground under their feet shakes and the turtle says that it may be 'Babylon's lions' coming. At the beginning, Safa and Ali think these are true lions, like them, but discover that these are nothing but humans. The turtle then tells them about the legend of the statue, that if kept safe, Iraq would never fall in the hands of outsiders. The statue is for a man fighting a lion that is attacking him. When they ask about the symbolical meaning of the man and the lion, and whether they are on the man' s side or the lion's side, the turtle says that it does not know because "Walkers never say what they mean" (61). Then, the earth shakes again and the lions find themselves facing a countless number of tanks destroying everything in their way. The lions try to escape and search for something to eat. Safa and Noor fight once more again and Noor decides to go with Ali to find a prey, but Ali refuses to leave Safa. In the same panel, Ali finds traces of blood and calls them where they find a dead man lying on the ground. Safa refuse to eat the man just because he is one of the keepers who used to keep them alive and safe in the zoo. Zill, refuses her logic telling her that this loyalty should be only for their own pride.

In a later scene, the lions see a group of horses and mistake them for gazelles, but they find them hornless; for them the horses are just "white things" (107). This group represents a typical prey for them,

العدد الرابع والعشرون (الجزء الثالث) 2018

()

بجلة كلية التربية- جامعة عين شمس104 
but another bombing prevents them and they run away. Searching for the horses, Safa and Noor are sent by Zill to hunt for the horses. They are the females who should go hunting, not the males. Noor and Safa are driven into what they imagine to be a cave, but is really a palace of one of Saddam's sons. It is Uday Hussien who was known for keeping lions as pets in all his palaces throughout Iraq. There, they hear a voice: "Master... is that you...?" (89). This voice turns to be that of a severely wounded lion who tells that they can never know him if they still keep their claws and teeth. His claws and teeth, like the others kept with him in such a palace, were taken off. When Noor and Safa say that they cannot understand, the wounded lion says that they should "Be thankful for that" (89). When Safa says that it could not be the 'keepers' who did this because they have never been "tortures" though they were "captors", Noor replies, "no matter how they might treat us, those who would hold us captive are always tyrants" (90). In a direct reference to the American invasion of Iraq, Noor is pointing to the fact that no country is given excuse for invading another just to give its people their freedom. Again, no governor is given the right to practice tyranny and despotism just because he is able to keep his people safe and sound.

In another master scene that ends up the novel, the lions reach up to the top of a hill where they, at last, can clearly see the horizon. At the same moment of feeling their ultimate freedom, the lions are shot dead. The first panel in the next page is a picture of the American flag and it proceeds to another panel showing a group of soldiers coming in asking what was that; they then see the lions. One of the soldiers claims that the lions have attacked them saying, "IT ...IT CHARGED RIGHT AT US SIR"(121). What is more surprising to the readers, who witness the whole scene, is that the commander says, "YOU DIDN'T HAVE A CHOICE I KNOW." (121).When one of the soldiers asks if these creatures go wild in such places i.e. Iraq, there comes an answer that they are not wild,

2018 العدد الرابع والعشرون (الجزء الثالث)

()

بجلة كلية التربية- جامعة عين شمس105 
but "THEY' RE FREE" (121). In the next panel, the readers see the croak high up in the sky with his mouth open as if speaking commenting on the scene, together with a group of military planes throwing bombs on Baghdad. In this scene, it is worth noting to comment on the use of the capital letters in the words of the American soldiers. This symbolically refers back to the hegemony of the American policy and its influence on the whole world. Though the commander did not see the lions and does not know exactly whether they attacked the soliders or not, he instantly believes the solider, who represents the American leader George Bush convincing the whole European world to back him up in his war against Iraq. Structurally speaking, the crow serves structurally here as an internal link that gets the last scene held tight together with the first scene of the novel since it is the croak who introduces the war, that gets to frame the whole novel.

Written in the form of a graphic narrative, the novel knocks heavily on impressionism as an underlying method of interpretation. Impressionism is based on the proposition "that reality is a synthesis of sense experiences, and that the distinction between subject and object is misleading. What is real is the object-as-experienced by a perceiver" (E. Quinn 210). The relationship between impressionism and graphic novels comes from the fact that in a graphic novel, the readers use more sense to drive the meaning; they read words, look at pictures and imagine what lies beyond them to construct their own mental images. In addition, held within an impressionistic context, the work does not reflect an idea as much as the sensation of this idea. In other words, the aim is "to direct pictorial means toward the expression of 'Ideas' rather than the representation of objects." (Shiff 7). In The Pride of Baghdad, for example, what is transferred to the readers is not the state of war, but how it feels to experience it. Consequently, the mental image drawn exceeds the drawn pictures, depending on the subjectivity of the readers

2018 العدد الرابع والعشرون (الجزء الثالث)

()

بجلة كلية التربية- جامعة عين شمس106 
themselves. What the image triggers in the emotional milieu of the reader is what really matters. For example, if a Palestinian reads the novel, he/ she directly reflects on the his/ her own experience of oppression since what he/she conceives is an emotional state more than a certain fixed idea.

In addition, this impressionistic flavor makes the readers, all the time, conscious of what is happening and aware of the link to their own current status. Versaci asserts this when he proposes that one can never escape the present while reading comics "because its form- impressionistic illustrations of people, places and thingsreminds us at every turn (or panel) that what we are experiencing is a representation." (6). In other words, the state of verisimilitude is always broken. A graphic narrative rests in its analysis on many modes of interpretation that lends the upper hand to the subjectivity of the reader and how s/he approaches the text together with the image. These modes, like the pace of the story, which mainly depends on the number of panels in one page, help the readers to move from one stage to another. Next, there are the perspectives that have to do with angles, whether high, low or eye-level, and shots that vary from long-shots, medium shots, close-ups and extreme close-ups. Then there are the tone and mood that are set by the help of the panel borders, lighting, color and contrast. In addition, there are the traditional literary tools that exist in ordinary novels like characterization, setting, plot, theme, etc. In short, graphic narratives make use of both cinematic and dramatic elements to extend the imaginary vision of the readers. All these cinematic and literary modes serve the function of light, in impressionism, in throwing hues of meaning to the original picture or text.

It is subjectivity that links impressionism and animal allegory, both used in the text as tools of interpretation, since both symbolism and impressionism depend mainly on subjectivity. It is subjectivity that

2018 العدد الرابع والعشرون (الجزء الثالث)

()

بجلة كلية التربية- جامعة عين ثمس 107 
makes it easy for people to understand impressionism because "when the sense of the impressionists' subjectivity and idealization becomes clear, so does the meaning that their art held for the symbolists." (Shiff 5). This means that it is the degree of subjectivity which the works permits that gives it its true meaning. Asserting the subjective nature of impressionism and symbolism, Shiff stats that "[ $\mathrm{t}]$ he impressionist's 'impression'-just as the symbolist's 'symbol'-represented a vision and a reality which (ideally) involved no extrapersonal or cultural mediation." (13). Consequently, the meaning here is contextualized in the person's own background and psyche more than derived objectively from the picture or text presented.

In the novel, the images are not additives as much as they are clues. To intensify the importance of the images, sentences are left incomplete sometimes as in "Don't listen to her child..." (16), and are started with three dots sometimes as in: "... I can assure you that Noor has no idea what killing a rabbit is like" (17). Ellipsis is a writing technique that is used powerfully in The Pride of Baghdad. It supports the graphic form in a unique way providing the reader with the chance to search for more information. Generally defined, it is "A rhetorical figure in which one or more words are omitted." (J. Cuddon 256). In the novel, the wide use of ellipsis is complemented by the pictures themselves. When the croak warns the other animals saying and repeating "The sky is falling" (9), the lion shouts out that he would swallow it if it did not stop saying this. At that moment, the lion is in a bad need to assure himself before the croak that everything is fine. In the next speech bubble he says, "the sky is never going to ..." (9). The word 'fall' is omitted as if this would prevent the sky falling actually. This example of ellipsis, together with the next panel portraying Zill looking upwards to the sky with a scared and confused look, presents the readers immediately to the main action of the novel. The next picture shows 
three military planes glowing in the sky, and this glow is reflected in the red color in Zill's eyes. He shouts as if refusing to believe what he knows is going to happen. The close-up panel of Zill looking at the sky completes the previous panel of him threatening the croak. The two panels speak to each other with the first given the sky as background and the second given the land as a background.

All the time, ellipsis works well in The Pride of Baghdad to utter in its incompleteness the psychological havoc and uncertainity experienced at that time, functioning "as a means of promoting access to emotional or psychological states" (A. Tonner 1).The animals try to soothe themselves suggesting that the keepers are the ones who threw them the carcass of the donkey, but they turn to ask, "why would the keepers feed us an entire donkey right after we just..." (24). The ellipsis here shows a fear that is assured immediately in the next panel with a picture showing the keepers running and Zill saying, "They are leaving." (24). Noor asks, "who... the keepers?" and Zill shouts at her to take Ali to the den "before..." and stops. The next panel comes to complete his sentence with a picture of a bombing that throws the lions up in the air. After the bombing, Noor asks, "Are... are we dead?" (28). After the walls of the zoo are destroyed and the lions see the horizon outside the zoo, Zill says, with a very confused terrified look "...we're free" (29). The ellipsis, here, shows the instable psychological state Zill is experiencing, being himself doubtful about themselves being really free. The omission marks i.e. ellipsis, tells of something that cannot be said. The merge between pictures and incomplete utterances, leading all to reinforce the emotional effect of the novel, leads the discussion forward to the theory of braiding in graphic narratives

Braiding is a theory relating specifically to the narrative nature of graphic novels. It proposes that a "graphic narrative puts every panel in a potential, if not actual, relation with every other" (S. 
Horstkotte 41). Consequently, a panel is not just a picture that only serves the words in the accompanying speech bubble. More significantly, it is part of a larger mental image that is to be formed in the mind of the reader while reading the novel. This acts perfectly in supporting one of the main features of graphic novels concerning the fact that they "help facilitate reading in one particular direction by being composed in such a manner that the eye of the reader moves easily from one action to another" (Petersen xviii). In one of the panels, Safa's words are written without appearing herself physically in the picture. However, the next panel comes with Safa, in person, completing the words she has uttered in the previous panel. This, actually, introduces the conflict between her and Noor creating a kind of suspense, on the part of the reader. Then comes the next panel to gather the four main characters of the novel together, for the first time, each showing a different view point concerning the topic of freedom. As a result, it is worth noting here that the theory of braiding argues that "a single panel only acquired meaning in a sequence, but it is always part of multiple sequences of varying length, from the triad of preceding, current, and following panel" (Horstkotte 41). The young male Ali is with his young female Noor in the first panel; the old male Zill is with the old female Safa in the second panel; and the four characters are held together in the third panel, with Zill and Safa facing the readers who see only the backs of Noor and Ali. Here, there is a hint that supports Safa and Zill as representatives of age and experience in handling all affairs.

Getting everything back together, it is easy to find a strong link between the graphic form of The Pride of Baghdad and its thematic content i.e. war, to be tackled and traced within the framework of formalism represented in defamiliarization as a representative critical literary term. As a result, The Pride of Baghdad proves ideal to be read within the framework of formalism as a critical literary 
approach. Here, the form is foregrounded to speak out about war and freedom as the main thematic threads that run along the novel. Defamiliarization is achieved in the novel through two main tools: the graphic form of the narrative, on one hand, and the animal allegory, on the other. Depending on images together with words to formulate the main message, the novel is given an impressionistic flavor. Again, ellipsis is brought in as a technical factor that consolidates the effect of the drawn images by urging the readers to read the pictures in order to make up for the missing words. Animals constitute the main characters of the novel bringing in the theme of otherness that sprouts from the theme of freedom as a thematic backbone for the novel. The novel ends in a scene that answers the question usually posed concerning freedom. Freedom is not concerned with how to get out of borders, but with how to regulate rights and duties without creating chaos. The Pride of Baghdad proves a rich medium for more literary analysis. For example, feminism could be a potential approach to be taken for further researches on the novel. The relationship between Zill and Safa, Zill and Noor, Ali and Safa, Ali and Noor, and most importantly between Noor and Safa could be traced artistically throughout the whole novel. Again, eco-criticism is another potential field of analysis, basically depending on tracing and analyzing the human/ non-human dichotomy in the novel.

\section{Notes:}

1- The Pride of Baghdad is one of the graphic novels that do not have page numbers. The pages used in this research are that of the PDF version of the novel. 


\section{Works Cited}

Barthes, Roland. The Rustle of Language. Translated by Richard Howard. Berkeley, Los Angeles: University of California Press, 1989.

Browne, Anthony. "The Role of the Author/Artist" in What's in the Picture: The Meaning of

Illustrations in Picture Books. Eds. J.Evans. London: Paul Chapman, 1998.

Gravett, Paul. Graphic Novels: Everything You Need to Know. New York: Collins Design, 2005.

Horstkotte, Silke. "Zooming In and Out: Panels, Frames, Sequences, and the building of Graphic Storyworlds" in From Comic Strips to Graphic Novels: Contributions to the Theory and History of Graphic Narrative. Eds. Daniel Stein and Jan-Noel Thon. Boston: De Gruyter, 2013.

James, Henry. "Henry James's First Interview." Interview by Preston Lockwood. The New York Times, 21 Mar. 1915.

Kanneh, Kadiatu. African Identities: Race, Nation and Culture in Ethnography, Pan-Africanism and Black Literatures. New York: Routeledge, 1998.

Kretschmar, Thomas and and Martin Tzschaschel. The Power of Inner Pictures: How Imagination Can Maintain Physical and Mental Health. Londoan, Karnac, 2017.

Mccloud, Scott. Making Comics: Storytelling Secrets of Comics, Manga and Graphic Novels.

London, Happer, 2006.

Meighoo, Sean. "The Function of HumAnimAllegory" in Humanities, 6:2 (2017). www.mdpi.com/2076-0787/6/1/2/pdf-vor . Accessed 27 Aug. $\underline{2018}$

Pedersen, Martin. "Comix at 100: Still Growing." Publishers Weekly 12 June 1995: 32-39.

Quin, Edward. A Dictionary of Literary and Thematic Terms. New York: Infobase Publishing, 2006. 


\section{Dr. Engy Salah Tawfeek Saleh}

Petersen, Robert. Comics, Manga, and Graphic Novels: A History of Graphic Narratives. Oxford: Praeger, 2011.

Shaw, Bruce. The Animal Fable in Science Fiction and Fantasy. London: MacFarland, 2010.

Shiff, Richard. CEZANNE and the End of Impressionism: A Study of the Theory, Technique, and Critical Evaluation of Modern Art. Chicago: The University Of Chicago Press, 1984.

Shklovsky, Victor. "Art as Technique" (1965), Modern Criticism and Theory: A Reader. Ed.

David Lodge. London: Longman, 1988, pp. 16-30.

Thon, Jan-Noel. "Who's Telling the Tale? Authors and Narrators in Graphic Narrative" in From Comic Strips to Graphic Novels: Contributions to the Theory and History of Graphic Narrative. Eds. Daniel Stein and Jan-Noel Thon. Boston: De Gruyter, 2013.

Toner, Anne. Ellipsis in English Literature: Signs of Omission. Cambridge: Cambridge University Press, 2015.

Vaugan, Brian K. Writer. The Pride of Baghdad. Illus./ Nico Henrichon. New York: DC Comics, 2006.

Versaci, Rocco. This Book Contains Graphic Language: Comics as Literature. New York: Continuum, 2007.

Weiner, Robert G. (Ed.). Graphic Novels and Comics in Libraries and Archives : Essays on Readers, Research, History and Cataloging. London: McFarland \& Company, 2010. 
A Formalist Reading of the Graphic Novel The Pride :Defamiliarizing War of Baghdad

2018 العدد الرابع والعشرون (الجزء الثالث) 